\title{
Factors That Will Influence Oil and Gas Supply and Demand in the 21st Century
}

\author{
Stephen A. Holditch (Texas A\&M University, USA) \\ Russell R. Chianelli (University of Texas at El Paso, USA)
}

\begin{abstract}
A recent report published by the National Petroleum Council (NPC) in the United States predicted a $50-60 \%$ growth in total global demand for energy by 2030 . Because oil, gas, and coal will continue to be the primary energy sources during this time, the energy industry will have to continue increasing the supply of these fuels to meet this increasing demand. Achieving this goal will require the exploitation of both conventional and unconventional reservoirs of oil and gas in an environmentally acceptable manner. Such efforts will, in turn, require advancements in materials science, particularly in the development of materials that can withstand high-pressure, high-temperature, and high-stress conditions.
\end{abstract}

\section{Introduction}

The National Petroleum Council (NPC) in the United States recently published a report entitled "Facing the Hard Truths about Energy" that evaluates the oil and gas supply and demand in the early part of the 21 st century. ${ }^{1}$ The report was developed by more than 350 participants from diverse backgrounds, with input from over 1000 other persons and organizations. The report concluded that the total global demand for energy will grow by $50-60 \%$ by 2030 as a result of the increase in world population and higher average standard of living in many of the developing countries.

It is clear that the world can use all of the energy the industry can produce from oil; natural gas; coal; nuclear energy; and renewable energy sources, such as wind, sun, biofuels, and hydroelectric power. It is also clear that, for the next few decades, oil, gas, and coal will continue to be the primary energy sources. The energy industry will have to continue increasing the supply of the hydrocarbon fuels to meet the global energy demand.

There are ample hydrocarbon resources to meet the demand well into the 21 st century. Oil and natural gas volumes located in unconventional reservoirs, such as heavy oil, oil shales, tight gas reservoirs, gas shales, and coal seams, are much larger than what has been produced thus far, primarily from conventional reservoirs. The key to the future will be the development of new technology that allows the industry to produce oil and gas from these unconventional reservoirs in an environmentally acceptable manner.

Other factors will also affect both the supply and demand of oil and gas in the coming decades. One major factor is concern over the environment. As such, $\mathrm{CO}_{2}$ sequestration and environmentally friendly operations will be a large part of developing new resources. Other factors, such as technology breakthroughs in nuclear power, biofuels, or solar energy, can be expected to alter the demand for energy from hydrocarbons. Throughout the process, the development of materials, especially those that can withstand high-pressure, high- temperature, and high-stress conditions, will be important to the entire industry.

\section{World Energy Supply and Demand}

The NPC did not conduct its own grass-roots study of global supply and demand. Instead, the NPC collected the relevant documents and prior supply-and-demand studies; evaluated them; and used its best collective, organizational judgment to interpret the consensus of the experts who have studied world supply and demand in the recent past. The study can be downloaded from the NPC Web site (www.npc.org; accessed January 2008). Figure 1 illustrates several projected world energy growth scenarios from the International Energy Agency (IEA). ${ }^{2}$ The NPC adopted the IEA work as the best estimates. One clear picture from the NPC study is that the demand for energy will increase by $50-60 \%$ between now and 2030 as a result of increases in global population and the desire to increase the standard of living, especially in developing countries.

If indeed energy demand will increase by $50 \%$ between now and 2030, the logical question is: "How will the energy industry

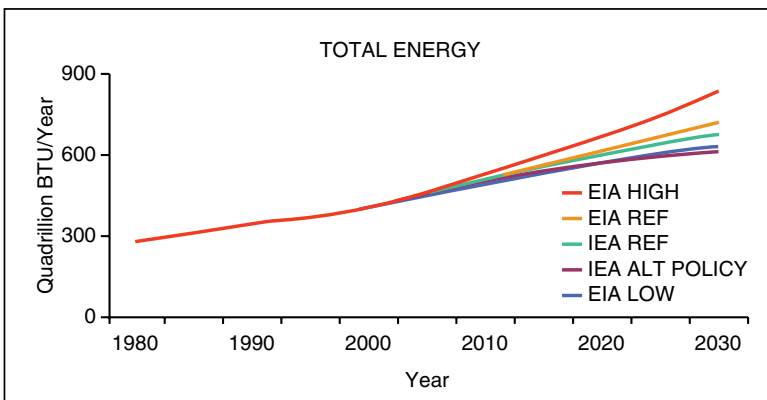

Figure 1. Several projected world energy growth scenarios from the U.S. Energy Information Administration (EIA) and the International Energy Agency (IEA). ${ }^{2}$ Note: REF, reference scenario; and ALT POLICY, alternative policy scenario. 


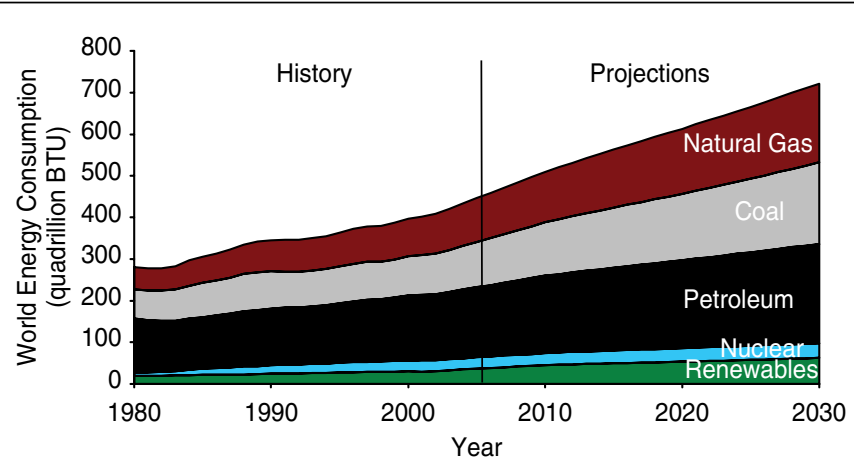

Figure 2. International Energy Agency best estimate for energy supply in 2030 (from U.S. Energy Information Administration reference case).

\begin{tabular}{|c|c|}
\hline \multicolumn{2}{|c|}{ Table I: Current Sources for World Energy Supply. } \\
\hline Energy Source & Supply Percentage in $\mathbf{2 0 0 5}$ \\
\hline Oil & 38 \\
\hline Natural gas & 23 \\
\hline Coal & 23 \\
\hline Nuclear & 7 \\
\hline Renewable & 9 \\
\hline
\end{tabular}

provide the supply?" Figure 2 presents the IEA best estimate for energy supply in 2030. It is clear that the major source of energy to meet the growing global demand for energy will be hydrocarbon fuels - oil, natural gas, and coal. Table I lists the sources of the energy that was supplied to the world in 2005. Hydrocarbon fuels contributed $84 \%$ of this energy. In 2030, the NPC predicts that hydrocarbon fuels will still make up $80 \%$ of the energy sources. Nuclear and renewable fuels will increase substantially, but will still be a minor part of the energy mix.

\section{Oil}

The global demand for oil in 2000 was 76 million barrels per day (bbl/day). Oil production is currently about 86 million bbl/ day, equivalent to 40,000 gallons/s or 31.4 billion bbl/year. The NPC estimates the demand for oil will be 103-138 million bbl/ day, or 37.6-50.4 billion bbl/year, by 2030 .

As stated in the NPC report, "Global, conventional oil reserves are concentrated in the Middle East. The seven countries with the

\begin{tabular}{|c|c|}
\hline \multicolumn{2}{|c|}{ Table II: Longevity of Supply for Selected Countries. } \\
\hline Country & $\begin{array}{c}\text { Years Remaining for Current Oil } \\
\text { Reserves Producing at Current } \\
\text { Oil Flow Rates }\end{array}$ \\
\hline Saudi Arabia & 75 \\
\hline Iran & 87 \\
\hline Iraq & 168 \\
\hline Kuwait & 105 \\
\hline United Arab Emirates & 70 \\
\hline Russia & 20 \\
\hline Venezuela & 52 \\
\hline United States & 16 \\
\hline
\end{tabular}

largest conventional oil reserves account for more than $70 \%$ of the world total. Saudi Arabia holds approximately $20 \%$ of the conventional reserves." Table II presents the ratio of current booked oil reserves divided by current oil producing rate in selected countries. Notice that the countries in the Middle East have sufficient reserves to produce at current flow rates for at least the first half of the $21 \mathrm{st}$ century. In addition, these countries are still exploring and working to increase both reserves and deliverability in existing fields. Because of the use of new technology, the world oil reserves have been increasing during the past 12 years. Figure 3 shows the

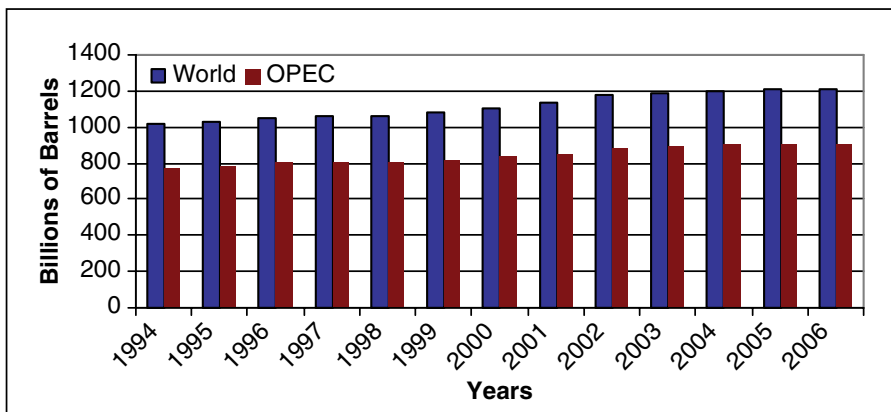

Figure 3. Increase in oil reserves from 1994 to 2006. Note: OPEC, Organization of the Petroleum Exporting Countries.

increase in oil reserves from 1994 to 2006. These data were obtained from the BP Web site (www.bp.com, accessed January 2008) and show that the global supply of oil is still increasing.

One widely asked question is: "So how much oil is left?" The answer is: "More than enough to fuel the world for many decades to come." Colin Campbell (a petroleum consultant and founder of the Association for the Study of Peak Oil \& Gas) studied the Petroconsultants worldwide database and concluded that, since inception, the oil industry had produced around 784 billion barrels of oil through the end of $1996 .^{3}$ Campbell acknowledged that the records were not perfect, but he believed his estimate was very reasonable. Taking Campbell's value of 784 billion barrels through 1996 and the global oil production values from the BP Web site for the past 10 years, the oil industry has produced around 1063 billion or 1.063 trillion barrels of oil since the industry began in the late 1800 s.

The data in Figure 3 clearly show that the industry believes it can produce another 1.25 trillion barrels from known fields through developmental drillings at different vertical horizons and lateral extensions of the fields. Thus, the industry has produced around 1 trillion barrels to date and believes that it can produce the second trillion in the 21 st century. The Society of Petroleum Engineers recently held a research conference focusing on the technology needed to produce the third trillion barrels. Considering the information just discussed, it is clear that oil will not run out any time soon.

\section{Natural Gas}

The situation for the natural gas supply is even more optimistic than that for oil. The world production of natural gas in 2000 was 243 billion cubic feet (bcf) (i.e., 6.88 billion cubic meters, bcm) per day or 88.7 trillion cubic feet (tcf) ( 2.51 trillion cubic meters, tcm) per year. In 2030, the NPC projects that the demand will increase to $356-581 \mathrm{bcf} /$ day $(10.0-16.5 \mathrm{bcm} /$ day) or 130-212 tcf/year (3.7-6.0 tcm/year). Most of the natural gas is currently used in North America, Europe, and Russia to generate electricity, generate heat, and satisfy a variety of residential and commercial uses. 
The NPC suggests that the global "gas-in-place" number (total amount of gas in a reservoir) for natural gas is about $50,000 \mathrm{tcf}(1400 \mathrm{tcm})$, largely unconventional gas. (This estimate does not include gas hydrates, which are discussed in the accompanying sidebar by Rath.) They also suggest the industry has already produced $3,000 \mathrm{tcf}(85 \mathrm{tcm})$ and has remaining reserves of $7,000 \mathrm{tcf}(200 \mathrm{tcm})$, which implies the industry knows where the remaining reserves are located and believes it can produce the gas economically.

As with oil, much of the natural gas reserves are in the Middle East, approximately $44 \%$. The remaining gas is distributed with $18 \%$ in Europe and Eurasia (mostly Russia), $11 \%$ in Asia, 10\% in Africa, and the rest in North America and South America. The largest natural gas reserve holders are Russia, Iran, Qatar, Saudi Arabia, the United Arab Emirates, and the United States. In the coming decades, much of the natural gas in the Middle East will be converted to liquid natural gas or liquid fuels and exported to Europe and North America.

\section{Unconventional Resources}

"Unconventional resources" is a term commonly used to refer to reservoirs that produce oil or gas at very low flow rates because of low permeability, geologic complexity, or high fluid viscosity. Many of the low-permeability reservoirs that have been developed in the past are sandstone, but significant quantities of unconventional oil and gas are also produced from lowpermeability carbonates, shales, and coal seams.

Unconventional reservoirs can be defined as natural gas or oil that cannot be produced at economic flow rates or in economic volumes unless the well is stimulated by a large hydraulic fracture treatment, a horizontal wellbore, multilateral wellbores, or an exotic technique such as steam injection.

The optimum drilling, completion, and stimulation methods for each well are a function of the reservoir characteristics and the economic situation. Unconventional oil and gas reservoirs in North America can have reservoir properties that are significantly different from those in South America or the Middle East. The costs to drill, complete, and stimulate these wells, as well as the product prices and the market, affect how unconventional reservoirs are developed.

\section{The Resource Triangle}

The concept of the resource triangle was used by Masters to find a large gas field and build a company in the 1970s. ${ }^{4}$ The concept is that all natural resources are distributed log-normally in nature. Prospectors for gold, silver, iron, zinc, oil, natural gas, or any resource will find that the best or highest grade deposits are small and, once found, are easy to extract. The hard part is finding these pure veins of gold or high-permeability oil

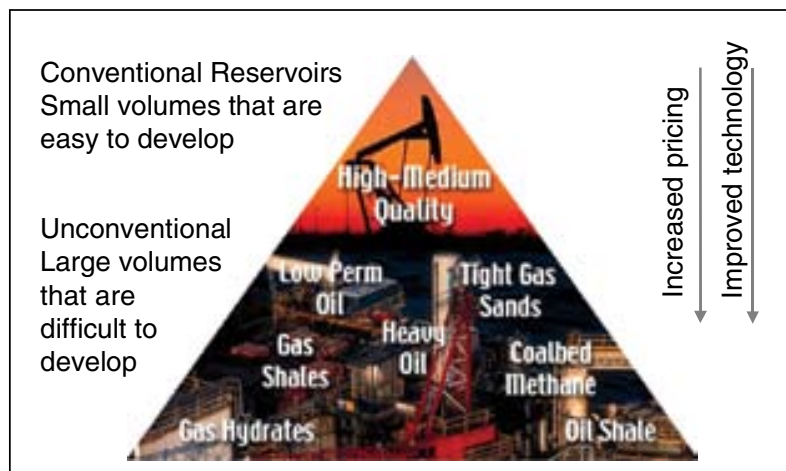

Figure 4. Principle of the resource triangle. and gas fields. Once the high-grade deposit is found, producing the resource is rather easy and straightforward. Figure 4 illustrates the principle of the resource triangle.

As one goes deeper into the resource triangle, the reservoirs are lower grade, which usually means that the reservoir permeability is decreasing or the oil viscosity is increasing or both. These low-permeability reservoirs, however, are usually much larger than the higher quality reservoirs. As with other natural resources, low-quality deposits of oil and gas require improved technology and adequate product prices before they can be developed and produced economically. However, the size of the deposits can be very large compared to that of conventional or high-quality reservoirs. The concept of the resource triangle applies to every hydrocarbon-producing basin in the world. One can estimate the volumes of oil and gas trapped in low-quality reservoirs in a specific basin by knowing the volumes of oil and gas that exist in the higher quality reservoirs.

\section{Unconventional Gas}

Outside the United States, with a few exceptions, unconventional gas resources have largely been overlooked and understudied. They represent a potential long-term global resource of natural gas and have not been appraised in any systematic way. Unconventional gas resources - including tight sands, coalbed methane, and gas shales - constitute some of the largest components of remaining natural gas resources in the United States. Research and development into the geologic controls and production technologies for these resources during the past several decades has enabled operators in the United States to begin to unlock the vast potential of these challenging resources. These resources are particularly attractive to natural gas producers because of their long-lived reserves and stabilizing influence on reserve portfolios.

From a global perspective, tight gas sand resources are vast, but undefined. No systematic evaluation has been carried out on global emerging resources. The magnitude and distribution of worldwide gas resources in gas shales, tight sands, and coalbed methane formations has yet to be understood. As shown in Table III, however, worldwide estimates are enormous, with some estimates higher than $32,000 \mathrm{tcf}(910 \mathrm{tcm}) .{ }^{5}$ The probability of this gas resource being in place is supported by information and experience with similar resources in North America. The $32,000 \mathrm{tcf}(910 \mathrm{tcm})$ value is likely to be a conservative estimate of the volume of gas in unconventional reservoirs worldwide, because there are fewer data to evaluate outside of North America. As more worldwide development occurs, more data will become available, and the estimates of worldwide unconventional gas volumes will undoubtedly increase.

Unconventional resources have been an important component of the U.S. domestic natural gas supply base for many years. From almost nonexistent production levels in the early 1970s, unconventional resources, particularly tight sands, currently provide almost $30 \%$ of domestic gas supply in the United States. The volumes of gas produced from unconventional resources in the United States are projected to increase in importance over the next 25 years, exceeding production levels of $9.0 \mathrm{tcf}(0.25 \mathrm{tcm})$ per year, as shown in Figure 5.

Coalbed methane is one of the best examples of how technology can have an impact on the understanding and eventual development of a natural gas resource. Although gas has been known to exist in coal seams since the beginning of the coal mining industry, only since 1989 has significant gas production been realized. Coalbed methane (CBM) was drilled through and observed for many years, yet never produced and sold as a resource. New technology and focused CBM research ulti- 
Table III: Distribution of Worldwide Unconventional Gas Resources.

\begin{tabular}{|c|c|c|c|c|}
\hline Region & $\begin{array}{c}\text { Coalbed } \\
\text { Methane (Tcf) }\end{array}$ & Shale Gas (Tcf) & $\begin{array}{l}\text { Tight-Sand Gas } \\
\text { (Tcf) }\end{array}$ & Total (Tcf) \\
\hline North America & 3,017 & 3,842 & 1,371 & 8,228 \\
\hline Latin America & 39 & 2,117 & 1,293 & 3,448 \\
\hline Western Europe & 157 & 510 & 353 & 1,019 \\
\hline $\begin{array}{l}\text { Central and Eastern } \\
\text { Europe }\end{array}$ & 118 & 39 & 78 & 235 \\
\hline Former Soviet Union & 3,957 & 627 & 901 & 5,485 \\
\hline $\begin{array}{l}\text { Middle East and North } \\
\text { Africa }\end{array}$ & 0 & 2,548 & 823 & 3,370 \\
\hline Sub-Saharan Africa & 39 & 274 & 784 & 1,097 \\
\hline $\begin{array}{l}\text { Centrally Planned Asia } \\
\text { and China }\end{array}$ & 1,215 & 3,528 & 353 & 5,094 \\
\hline $\begin{array}{l}\text { Pacific (Organization } \\
\text { for Economic } \\
\text { Cooperation and } \\
\text { Development) }\end{array}$ & 470 & 2,313 & 705 & 3,487 \\
\hline Other Asia Pacific & 0 & 314 & 549 & 862 \\
\hline South Asia & 39 & 0 & 196 & 235 \\
\hline World & 9,051 & 16,112 & 7,406 & 32,560 \\
\hline
\end{tabular}

pores, free gas in natural fractures, and adsorbed gas on organic matter and mineral surfaces. These different storage mechanisms affect the speed and efficiency of gas production. Shale gas reservoirs represent some of the most important development opportunities in North America. Undoubtedly, gas from shales around the world will be produced and will become an important asset in the coming decades.

\section{Unconventional Oil}

Unconventional oil is found in low-permeability formations, heavy oil deposits, tar sands, and oil shales. Given that they are near the base of the resource triangle, both increased oil prices and bettertechnology are required to produce oil from these lowproductivity reservoirs. In the NPC study, the world endowment of liquid hydrocarbons is suggested to be on the order of 13-15 trillion barrels. Much of this endowment is in unconventional, heavy oil reservoirs and will be difficult to produce.

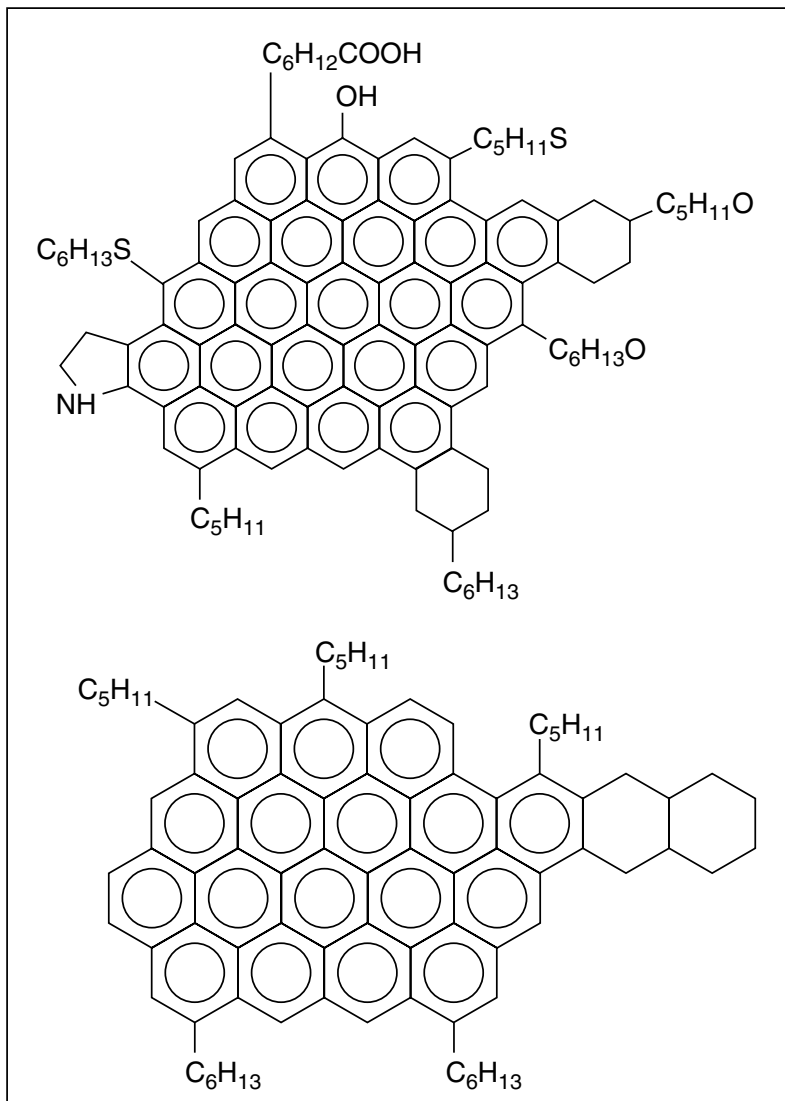

Figure 6. Macrostructure of asphaltenes precipitated from crude oils (see Reference 6). mately solved the resource complexity riddle and unlocked its production potential. Coalbed methane now provides over $1.6 \mathrm{tcf}(0.045 \mathrm{tcm})$ of gas production per year in the United States and is under development worldwide including in the countries of Canada, Australia, India, and China.

Deposits of coal reserves are available in almost every country throughout the world. Over 70 countries have coal reserves that can be mined and provide for potential CBM recovery. In 2005 , over five billion tons of coal were produced worldwide. The top 10 countries (China, United States, India, Australia, South Africa, Russia, Indonesia, Poland, Kazakhstan, and Columbia) produced nearly $90 \%$ of the total. Estimates of gas in place around the world in coal seams range from $2,400 \mathrm{tfc}$ to $8,400 \mathrm{tcf}$ (from $68 \mathrm{tcm}$ to $240 \mathrm{tcm}$ ). Assuming the United States to be representative, it is reasonable to expect that coal seams around the world hold potential for coalbed methane production. Worldwide coal resources are found in over 100 geologic basins.

Shale formations act as both a source of gas and its reservoir. Natural gas is stored in shale in three forms: free gas in rock 
Upgrading of heavy hydrocarbons requires an understanding of molecules called asphaltenes (see Figure 6). Asphaltenes are micellar molecules that are remnants of the original biomass that produced the hydrocarbons. They contain aromatic cores with long saturated side chains that solubilize the asphaltene in the crude. They also contain most of the metals ( $\mathrm{V}$ and $\mathrm{Ni}$ ) and much of the sulfur and nitrogen in the heavy hydrocarbons. These properties inhibit upgrading of heavy hydrocarbons through conventional processes because catalysts are destroyed by depositing metals. All petroleums throughout the world contain asphaltenes except the very light crude oils. The more asphaltenes the crude oil contains, the heavier it is and the more difficult to convert. Thus, understanding and processing asphaltenes is the key to upgrading heavy petroleum products. The origin of these materials is unclear and remains an interesting fundamental problem in the origins of petroleum. Recently, it has been shown that asphaltenes can spontaneously assemble under laboratory conditions. ${ }^{6}$ Asphaltenes themselves are interesting materials with many potential applications from producing carbon fibers to electrodes for fuel cells. Currently, asphaltenes are treated with steam to produce asphalt used to pave roads, thus the name asphaltene.

As already mentioned, the industry has produced a little more than 1 trillion barrels of oil from conventional sources so far and has another 1.25 trillion barrels identified as reserves. However, assuming that the industry will eventually unlock the secrets to producing heavy oil reservoirs, it is estimated that one-third of the endowment can be produced, which suggests that the ultimate recovery of liquid fuels could be as high as 4.5 trillion barrels, well into this or the next century.

Much of the unconventional oil currently being produced is found in North America, South America, and Indonesia, but significant volumes can be found in other basins around the world. The industry has developed drilling and stimulation technologies to allow production of heavy oil in all three regions. Additional technology developments will be required, but as demand increases, the incentives to develop such technologies will also grow.

\section{Technology Requirements}

Regardless of the type of unconventional resource one is trying to develop, technology advancements are needed in virtually every technical category, including drilling, formation evaluation, reservoir engineering, well stimulation, and completion methods. The technology must focus on both getting more oil and gas out of the reservoir and reducing the costs to find and produce the oil and gas. Better technology for materials and electronics that can withstand high-pressure, high-temperature (HPHT) conditions will allow the industry to drill deeper wells that will increase the oil and gas supply from these deeper horizons worldwide. Better arctic technology is also needed.

As discussed in the NPC report, most technologies in most industries take 20 years to commercialize and become standard. Even in the oil and gas industry, commercialization of new technology takes an average of 16 years to progress from concept to widespread use in the industry.

\section{Technology for Unconventional Gas}

Hydraulic fracture fluids are among the more pressing technology needs confronting operators in unconventional gas reservoirs. The objective of pumping a fracture treatment is to fracture (crack) the reservoir rock around the bore hole and place propping agents (also called proppants) into the crack to prop the fracture open, thus forming a permeable conduit that allows gas to flow to the well bore. Polymer gel formulations are typically used to create the crack and carry the propping agents. However, gelled fluids can damage the fracture itself, particularly in formations where the temperature is less than $250^{\circ} \mathrm{F}\left(120^{\circ} \mathrm{C}\right)$.

What the industry needs is a viscous fluid system that can transport a propping agent deeply into a fracture and then cleanly break back to a low-viscosity fluid so that it can be produced back from a low-temperature reservoir. Originally, sand was used as the propping agent for hydraulic fracture treatments. However, silica sand crushes severely when the stress is $6,000 \mathrm{psi}(41,000 \mathrm{kPa})$ or higher, and sand will dissolve in hot salt water, which is often found in deep reservoirs. In the early 1980s, the industry started using sintered bauxite spheres to prop open fractures. Later, lower density but strong ceramic beads were introduced. Bauxite and ceramic beads work well, but they are dense and difficult to transport deeply into a formation down the fracture. An optimal propping agent would be a material that has a density of less than $2 \mathrm{~g} / \mathrm{cm}^{3}$, is strong, and is corrosion resistant. The proppant should also not crush severely at stresses of $15,000 \mathrm{psi}(103,000 \mathrm{kPa})$ or more.

Although the industry is a long way from developing the ideal fracture fluid, new systems such as water-based viscoelastic surfactant fluids are offering solutions for some unconventional reservoirs. Viscoelastic fluids are polymer-free. The surfactant forms wormlike micelles in the presence of brine to increase fluid viscosity. Continued advancement in propping agent technology, such as the creation of strong, lightweight, inexpensive proppants, is also an important need for the industry.

Unconventional reservoirs tend to be very thick, and any technology to enhance perforating, fracturing, and completing ultralong intervals would have tremendous value, especially in multiple-stage treatments. In certain types of reservoirs, oriented perforating tools are proving highly effective, allowing operators to initiate hydraulic fractures in the preferred plane and with the preferred orientation to natural fractures in the reservoir rock to improve proppant deliverability and enhance production.

\section{Technology for Reservoir Evaluation}

In reservoir evaluation, the ability to better locate productive sands and shales and then delineate the "sweet spots" (those areas of the productive interval where permeability is highest and gas flow is least restricted) is one of the keys to economic development. Simply put, the sweet spot is where most of the production occurs and where operators make most of their profit. Geophysical and petrophysical technologies are needed to help define the best parts of reservoirs. Some technologies are currently in use, such as amplitude variation with offset, and other seismic techniques can help find the gas zones. In addition, a new class of nuclear magnetic resonance logging tools has the potential to deliver the detailed permeability information needed to pinpoint sweet spots in the vertical section and optimize completions.

\section{Technology for Unconventional Oil}

As with natural gas, technologies used to develop and produce unconventional oil must advance to allow economic production. The major production methods are open pit mining, cold production using horizontal wells, cyclic steam injection, steam flooding, and steam-assisted gravity drainage (SAGD).

Finding unconventional oil sources is a challenge in itself. A new detection technique for this purpose is electroseismic hydrocarbon detection. The technique is fully field-tested and holds the promise of not only hydrocarbon detection, but also on-line monitoring and control of tar sands production in the field. The technique is based on the electroseismic or electroacoustic effect. An electric field, applied to a porous material that contains an ionic solution, causes a displacement between charges on the porous material and the ions in solution. This 
relative displacement induces pressure in the pore space and the porous matrix. In an alternating-current (ac) applied electric field, the pressure response of the matrix takes the form of an acoustic or seismic wave. The nature of the detected signal is determined by the physical properties (ionic or conducting properties) of liquids in the pores. A rock filled with water gives a different response from a rock filled with oil. Thus, one of the ultimate dreams of petroleum exploration has been realized. Moreover, this technique certainly has many other potential applications in materials science.

Many hydrocarbons are located remotely in tars sands (Canada) or bitumen lakes (Trinidad). These resources contain huge amounts of energy if they can be mined and converted to lighter oils. Recovering these hydrocarbons essentially involves heating them with steam and then separating the hydrocarbons and subjecting them to further treatment. These processes create huge environmental problems including large amounts of contaminated water that must be re-injected into the original formation or otherwise treated. The hydrocarbons that are recovered are low in value, containing large amounts of sulfur and other pollutants that must be removed. Researchers are working on new catalytic processes and equipment to upgrade the hydrocarbons at the site of production. These upgrading units will be modular and mobile, requiring novel materials to achieve the flexibility needed. Ultimately, there is a desire to upgrade the hydrocarbons in situ. Doing this will require new catalysts that can be injected into the formation and allowed to work for longer periods of time in order to produce "pipelineable" hydrocarbon fuel. Indeed, research is proceeding in this area. In SAGD wells, production can be improved using solvents along with the steam. In addition, some in situ combustion methods have been used in heavy oil reservoirs. Another possible production method is downhole electric heating.

In steam wells and in deep gas plays (i.e., a group of fields with similar trap structures and reservoir rock) around the world, the development of materials that can withstand high pressures $[\geq 15,000 \mathrm{psi}(\geq 103,000 \mathrm{kPa})]$, high temperatures $\left[\geq 400^{\circ} \mathrm{F}\left(\geq 200^{\circ} \mathrm{C}\right)\right]$, and corrosive environments $\left(\mathrm{CO}_{2}\right.$ and $\mathrm{H}_{2} \mathrm{~S}$ ) will be an important technology area. In horizontal drilling, there is a need for downhole electronic equipment that can withstand these HPHT conditions. In many cases, insulating these electronic tools is the key to providing long-lived service. In other cases, the metallurgical design of the downhole tubular goods that can withstand HPHT corrosive environments is the key to success.

\section{Constraints to Meeting Energy Demand}

It appears evident that energy demand will continue to increase well into the 21 st century. It also appears evident that ample hydrocarbon resources are available to meet the demand, although significant constraints will affect progress toward this end. The most important of these constraints are $\mathrm{CO}_{2}$ emission standards, research expenditure limitations, capital requirements, manpower limitations, and access to drilling locations.

\section{Environmental Constraints}

In the NPC report, much of the discussion involves the realization that, to continue using hydrocarbon fuels, the world must develop the technology, as well as the legal and regulatory framework, to enable carbon capture and sequestration. Indeed, the report recommends the establishment of a global framework for carbon management, including a transparent and predictable cost for $\mathrm{CO}_{2}$ emissions. The development of clean-burning coal technology to address $\mathrm{CO}_{2}$ emissions will be very important in allow- ing the continued use of coal for the generation of electricity, freeing up the use of natural gas for other applications.

In addition to $\mathrm{CO}_{2}$ emission issues, the industry must acknowledge and resolve issues involving land use, waste disposal, habitat, and noise. Research must continue on environmentally friendly drilling and production methods. For example, the industry should continue to develop green chemicals that can be used in wellbores. The cost of doing business involves being stewards of the environment wherever the industry is operating.

\section{Technology Constraints}

The research intensity, measured in terms of the research expenditure as a function of the percentage of sales, is low in the oil and gas industry compared to other industries, such as pharmaceuticals, transportation, and computers. It can be argued that some research is conducted on every well drilled and completed; however, not much learned on individual wells is recorded and put to use elsewhere. Most studies, such as the one recently performed by the NPC, suggest that the industry and governments in oil-producing countries should be putting more money into research and development. After all, developing and using better technology is the key to unlocking the oil and gas located near the bottom of the resource triangle.

\section{Manpower and Capital Constraints}

As the industry continues to find more oil and gas in conventional reservoirs, in the Arctic, in deep water, and in unconventional reservoirs, many more wells will have to be drilled. This, in turn, means that more rigs, more equipment, more personnel, and more capital will be needed, as well as improved access to prospective lands and new pipeline infrastructure to market the oil and gas that is found. The NPC estimates that the worldwide investment in energy will be $\$ 20$ trillion during the next 25 years. Decisions will have to be made on how this money can be spent wisely.

In the next 10 years, over one-half of workers currently in the industry will be eligible to retire. The NPC recommends that governments support young men and women seeking engineering and other technical degrees, both graduate and undergraduate, by increasing funding for scholarships and research at universities. The NPC also recommends that the tax laws be changed to allow those who have retired to work part time without losing any of their retirement benefits.

\section{Access to Resources}

In many areas, especially in North America, access to known or promising deposits of oil and gas is restricted because of environmental concerns or, in many cases, because the residents simply do not want to have to look at a drilling rig or even a windmill. The NPC recommends that governments conduct national and regional basin-oriented resource and market assessments to identify opportunities to increase the oil, gas, and coal supply. The industry should continue to create technology for the environmentally friendly development of highpotential areas both onshore and offshore. Toward this end, the public should be educated about energy; its use; its benefits; and the need to have access to areas that hold large volumes of oil, natural gas, and coal.

\section{Conclusions}

On the basis of the information included in this article, much of which is contained in a recent NPC report, ${ }^{1}$ the current status and outlook for the oil and gas sector can be summarized as follows: The demand for energy worldwide is expected to increase by $50-60 \%$ in the next 25 years as a result of the 
increase in world population and the desire for all to increase their standard of living. During this time, the major source of energy is projected to remain hydrocarbon fuels - oil, gas, and coal. Indeed, these fuels are expected to supply around $80 \%$ of the energy in 2030 . The global endowments of oil, gas, and coal are considered to be ample to supply the world with fuel in most of the 21 st century. However, to meet demand, the energy industry will need technology improvements and will need to improve how it burns or uses fossil fuels to reduce $\mathrm{CO}_{2}$ emissions. Constraints that could affect such efforts and, thus, the supply of energy in the future, consist of environmental concerns, manpower limitations, technical issues, restrictions on access to the deposits, and availability of the capital needed to fund the projects. Technology improvements in materials, such as polymers, chemicals, propping agents, metals, composites, and electronics, must occur in areas where steam injection is required and in deep high-pressure, high-temperature reservoirs in order for the needed energy resources to be obtained in an environmentally acceptable manner.

\section{References}

1. Facing the Hard Truths about Energy-A Comprehensive View to 2030 of Global Oil and Natural Gas, (National Petroleum Council, Washington, DC 2007); www.npc.org (accessed January 2008).

2. World Energy Outlook 2006, (International Energy Agency, Paris, 2007); www.iea.org (accessed January 2008)

3. C.J. Campbell, The Coming Oil Crisis (Multi-Science Publishing, Essex UK, 1997).

4. J.A. Masters, AAPG Bull. 63 (2), 152 (1979).

5. H.-H. Rogner, "An Assessment of World Hydrocarbon Resources" (WP96-26, IIASA, Laxenburg, Austria, May 1996).

\section{Methane Hydrates: An Abundance of Clean Energy?}

\section{B.B. Rath (Naval Research Laboratory, USA)}

The discovery that gas hydrates (also called clathrate hydrates) can crystallize (Figure 1) as a solid by the combination of water and several types of gases exposed to low temperatures and elevated pressure goes back to the 1800s. French researchers were the first to report the formation of methane, ethane, and propane hydrates. ${ }^{1}$ Results of these studies remained as scientific novelties until the mid-1930s, when it was discovered in Germany that gas hydrates forming as solids above $0^{\circ} \mathrm{C}$ in gas pipelines blocked the flow of natural gas. ${ }^{2}$ This observation initiated a flurry of activities both in Europe and in the

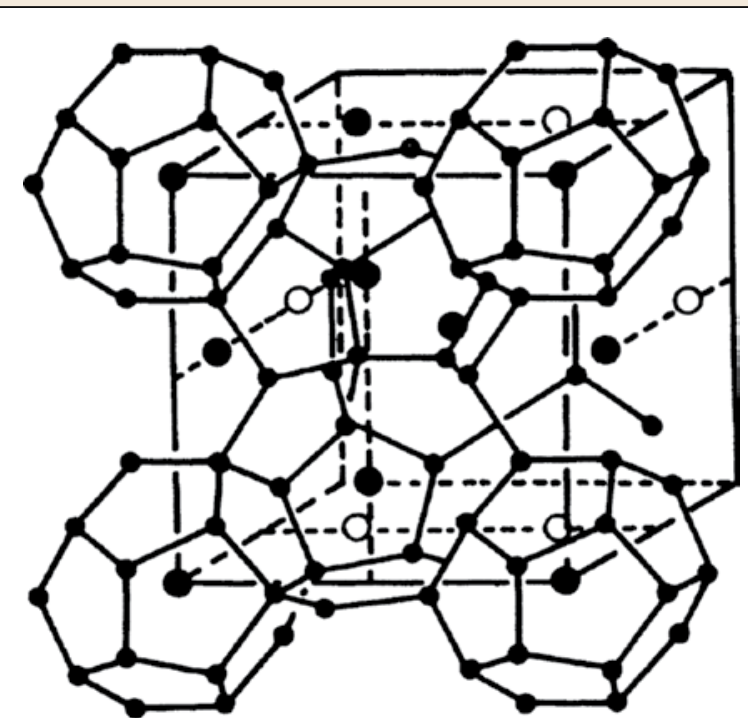

Figure 1. Crystal structure of hydrate composed of methane and water. The caged hydrate molecule aggregates into a cubic unit cell.
United States to find various inhibitors to prevent hydrate formation in gas transmission lines. During the mid-1960s, it was recognized that nature, over millions of years, has deposited vast amounts of methane hydrates along most of the continental margins in the ocean sediments, as well as along the permafrost regions in Alaska, Canada, and Russia. ${ }^{3}$ Figure 2 shows the presence of methane hydrate deposits in the ocean sediments and in the permafrost regions of the world. These deposits are byproducts of microbial decomposition of organic matter or of Earth's geothermal heating distributed worldwide where temperature and pressure are suitable for hydrate formation. The distribution of organic carbon in Earth's crust as methane

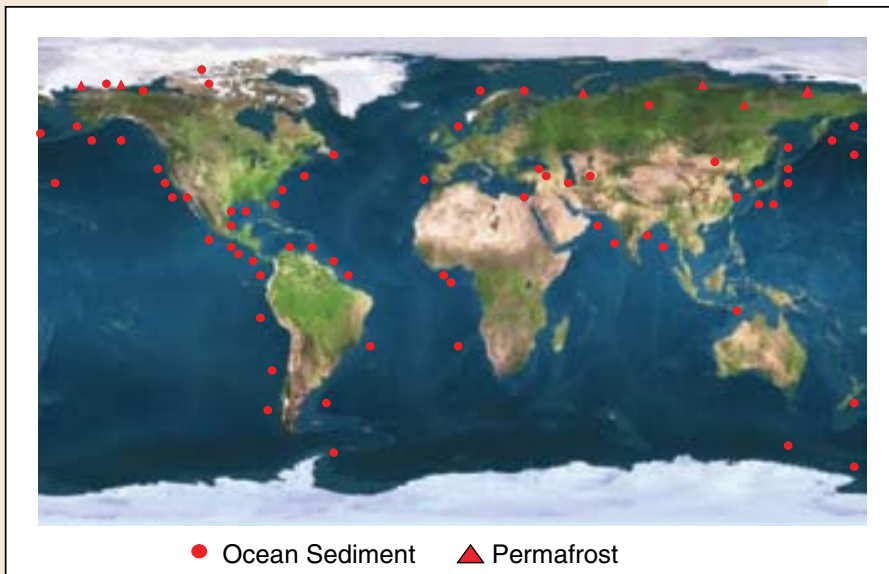

Figure 2. Global distribution of confirmed or inferred gas hydrate sites, 1997 (courtesy of James Booth, U.S. Geological Survey). This information represents our very limited knowledge. Gas hydrate is probably present in essentially all continental margins. 